\title{
Water Desalination and Bioelectricity Generation Using Three Chambers Microbial Salinity Cell Reactor with Electrolyte Recirculation
}

\author{
Rustiana Yuliasni ${ }^{1 *}$, Abudukeremu Kadier ${ }^{2,3}$, Nur Zen' ${ }^{1}$ Nanik Indah Setianingsih', \\ Setyo Budi Kurniawan², Peng-Cheng $\mathrm{Ma}^{3}$
}

1 Center of Industrial Pollution Prevention Technology, Ministry of Industry of the Republic of Indonesia, Jalan Ki Mangunsarkoro No. 6, Semarang 50136, Central Java, Indonesia

2 Department of Chemical and Process Engineering, Faculty of Engineering and Built Environment, Universiti Kebangsaan Malaysia, 43600 UKM Bangi, Selangor, Malaysia

3 Laboratory of Environmental Science and Technology, The Xinjiang Technical Institute of Physics and Chemistry, Key Laboratory of Functional Materials and Devices for Special Environments, Chinese Academy of Sciences, Urumqi, 830011, China

* Corresponding author's e-mail: rustianay@kemenperin.go.id

\begin{abstract}
Microbial Salinity Cell (MSC) can simultaneously desalinate water and generate electricity from the biodegradation of organic compound in wastewater. Utilization of a three-chambers configuration system along with electrolyte recirculation, creates a desalination process which occurs when the salt ions from the anode and cathode chambers are accumulated into the middle chamber, driven by the electrical energy generated from the organic compound biodegradation. The performance of three-chambers electrolyte recirculation MSC was investigated using three different $\mathrm{NaCl}$ concentrations of $2.0 \mathrm{~g} / \mathrm{L}, 4.0 \mathrm{~g} / \mathrm{L}$, and $8.0 \mathrm{~g} / \mathrm{L}$, with the acetate concentration of $0.82 \mathrm{~g} / \mathrm{L}$. At $2.0 \mathrm{~g} / \mathrm{L} \mathrm{NaCl}$, the maximum power density production was $42.76 \mathrm{~mW} / \mathrm{m}^{2}$, increasing conductivity in the middle chamber from $15.09 \mu \mathrm{S} / \mathrm{cm}$ to $0.74 \mathrm{mS} / \mathrm{cm}$. At $4.0 \mathrm{~g} / \mathrm{L}$, the maximum power density reached was $53.37 \mathrm{~mW} / \mathrm{m}^{2}$, and conductivity in the middle chamber was raised from $60.08 \mu \mathrm{S} / \mathrm{cm}$ to $2.74 \mathrm{mS} / \mathrm{cm}$. At $8.0 \mathrm{~g} / \mathrm{L}$, the power density was $29.29 \mathrm{~mW} / \mathrm{m}^{2}$ and conductivity in the middle chamber increased from $10.0 \mu \mathrm{S} / \mathrm{cm}$ to $1.65 \mathrm{mS} / \mathrm{cm}$. The performance of MSC was correlated with the initial $\mathrm{NaCl}$ concentration, with optimum $\mathrm{NaCl}$ concentration which was at $4.0 \mathrm{~g} / \mathrm{L}$, able to generate the highest power of $53.37 \mathrm{~mW} / \mathrm{m}^{2}$ and showed the highest increasing conductivity from 80.8 to $2.74 \mathrm{mS} / \mathrm{cm}$.
\end{abstract}

Keywords: electricity generation; electrolyte recirculation; Microbial Salinity Cell (MSC); three-chamber MSC; water desalination.

\section{INTRODUCTION}

Organic wastewater with high salinity content is mostly generated from the food and beverage industries such as fish processing, roasted peanut, and ketchup (Yuliasni et al., 2018). Due to the feasibility factor, highly organic wastewater is mostly treated using biological treatment (Kadir et al., 2020; Tangahu et al., 2019), while high salinity is efficiently removed by desalination. The desalination process using reverse osmosis (RO) to produce drinking water requires $3.70 \mathrm{kWh} / \mathrm{m}^{3}$ (Mehanna et al., 2010) while the wastewater treatment with high organic and high salinity content requires more intensive energy per meter cubic treated wastewater. In order to reduce desalination energy needed, as well as simultaneously remove the organic pollutants in the wastewater, a combination of Microbial Fuel Cell (MFC) and electrodialysis is introduced, namely Microbial Salinity Cell (MSC) (Zhang et al., 2019). 
The principle of MSC is different from Microbial Desalination Cell (MDC) (Cao et al., 2009; Wang and Ren, 2013) in which desalination occurs not in the middle chamber but in the anode chamber, concurrent with the chemical oxygen demand (COD) reduction. In the MSC system, recirculation is applied to minimize the imbalance $\mathrm{pH}$ problem that becomes a major bottleneck in the MDC system (Luo et al., 2012). In the future development, for more practical use, the main aim of the MSC technology is to treat complex high salinity wastewater (Zhang et al., 2019), either as pre-treatment technology or as advanced post-treatment technology (Fig. 1).

MSC consists of three chambers separated by cation exchange membrane (CEM) next to the anode and anion exchange membrane (AEM) next to the cathode. The anode chamber was filled with high saline organic wastewater. When current is generated by exoelectrogenic bacteria from the oxidation of organic pollutants in the anode chamber, the use of any external energy source for desalination is minimized $(\mathrm{Qu}$ et al., 2012). Protons will drift from the anode chamber to the salinity chamber, whilst the electrons will migrate from the cathode chamber, resulting in an increase of salinity in the salinity chamber (middle chamber). However, the flow of ions between chambers creates the $\mathrm{pH}$ imbalance, resulting in a lower $\mathrm{pH}$ in the cathode chamber. In order to minimize the imbalanced $\mathrm{pH}$, electrolyte recirculation from cathode to anode is needed to improve the extent of desalination and power density (Fornero et al., 2010).

The increase of the ionic conductivity is an important parameter for the development of bioelectrochemistry-based system. The study showed that the addition of low concentrations of salts in an MFC improves its performance by reducing the internal resistance (Liu et al., 2005). However, many microorganisms, especially Geobacter sulfurreducens, do not accept high salt concentrations due to the sensitivity to osmotic pressure (Rousseau et al., 2014). When the salt concentration is above $10 \mathrm{~g} / \mathrm{L} \mathrm{NaCl}$ (Gebauer, 2004; Ma et al., 2012), the internal resistance of the reactor is reduced due to inhibition of the microbial catalysis (Jannelli et al., 2017). Therefore, in this study, three different $\mathrm{NaCl}$ concentrations, with a maximum of $<10 \mathrm{~g} / \mathrm{L} \mathrm{NaCl}$, were used to study the effect of salt in MSC and the development of bioanode. Furthermore, the study on the MSC system was still limited compared to the MDC due to its complexity of parameters and operating conditions. This paper studied the performance of a three-chambers MSC in terms of power output and conductivity (which in correlation to salinity) as affected by different initial $\mathrm{NaCl}$ concentrations and the application of electrolyte recirculation.

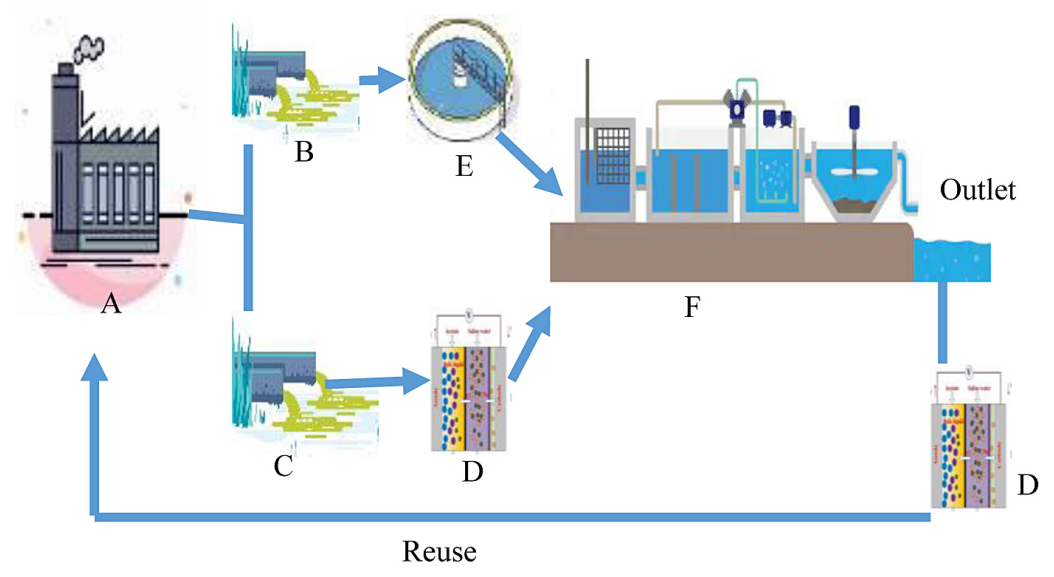
Legend
A: Food and beverage industry
B: Low strength high volume biodegradable wastewater
C: High strength high salinity low volume biodegradable wastewater
D: MSC
E: Preliminary treatment
F: Biological treatment (Activated Sludge)

Figure 1. Schematic illustration of the future application of the MSC in industry 


\section{MATERIALS AND METHODS}

\section{Reactor construction}

The MSC reactor was constructed based on three-chambers MFC, consisting of the anode, salinity (the middle chamber), and cathode chambers. The total volume of each reactor was $250 \mathrm{ml}$, filled with $200 \mathrm{ml}$ solution and $50 \mathrm{ml}$ headspace. The anode and salinity chambers were separated with Cation Exchange Membrane (CEM) (Nafion 117, The Fuel Cell Store, USA), while the salinity chamber and the cathode chamber were separated with Anion Exchange Membrane (AEM) (Fumasep FAS-30, The Fuel Cell Store, USA). A carbon rod wrapped with $0.03 \mathrm{mg} / \mathrm{cm}^{2}$ $20 \%$ platinum on Vulcan carbon cloth with a total working area of $63 \mathrm{~cm}^{2}$ was used as electrodes, for both anode and cathode. A platinum wire was attached to the electrodes as a current collector (counter electrode). The temperature in the anode chamber was maintained at $37 \pm 1^{\circ} \mathrm{C}$ using a hot plate (Thermo Scientific, USA). A small hose was installed from the cathode chamber to the anode chamber, circulated over, and was connected to the recirculation pump (Model 77120-52, Masterflex, Germany). The cathode compartment was left open and continuously aerated during the experiment. The schematic design and image of the reactor can be seen in Fig. 2.

\section{Microorganism and medium}

The seed microorganism was collected from frozen aerobic granule, warmed up at $37^{\circ} \mathrm{C}$ and was kept under anaerobic condition by spraying with nitrogen gas for five minutes, placed it in the sealed bottle and then inoculated for a week. The microorganism medium was referred to as DSMZ medium No. 826 for Geobacter sulfurreducens ("Geobacter Sulfurreducens Medium," 2016) with $0.82 \mathrm{~g} / \mathrm{L} \mathrm{Na}$-acetate was added as carbon source. Trace elements and vitamins were referred to as DSMZ medium 141 ("Sulfurovum lithotrophicum methanogenium medium (h 2 /co 2 ) DSMZ 141," 2014). The anolyte

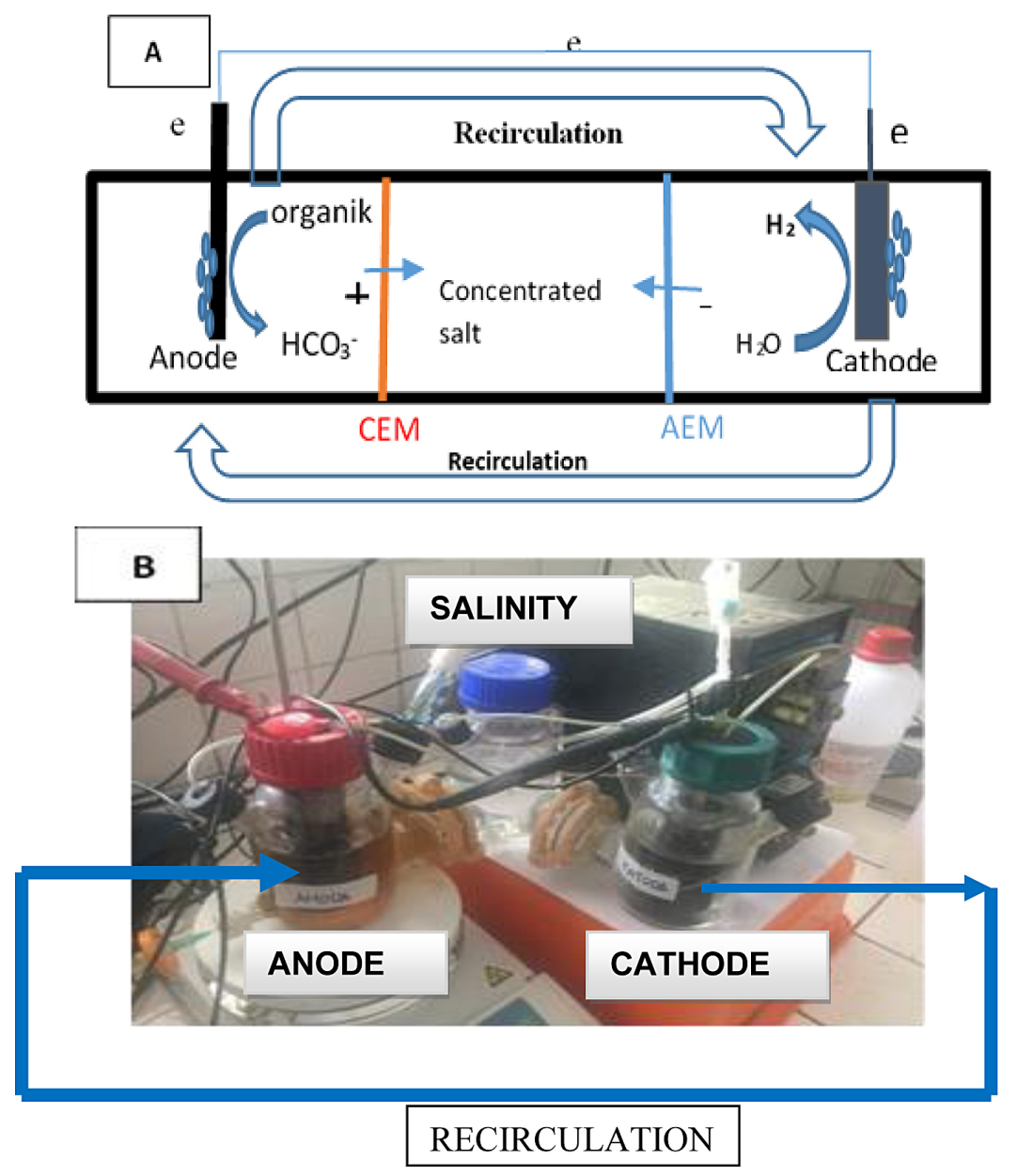

Figure 2. A) Schematic design of MSC with three-chambers configuration. B) Image of the MSC reactor 
composition is $40.0 \mathrm{ml}$ seed mix microorganisms, $140.0 \mathrm{ml}$ Geobacter medium, $10.0 \mathrm{ml}$ trace element and $10.0 \mathrm{ml}$ vitamin. The salinity (middle) chamber was filled with $200.0 \mathrm{~mL}$ of demineralized water. Meanwhile, the catholyte composition included $200.0 \mathrm{~mL}$ of $50.0 \mathrm{mM}$ phosphate buffer solution $\left(0.39 \mathrm{~g} / \mathrm{L} \mathrm{NH}_{4} \mathrm{Cl}, 2.69 \mathrm{~g} / \mathrm{L}\right.$ $\mathrm{NaH}_{2} \mathrm{PO}_{4} \cdot \mathrm{H}_{2} \mathrm{O}, 0.13 \mathrm{~g} / \mathrm{L} \mathrm{KCl}, 4.339 \mathrm{~g} / \mathrm{L} \mathrm{Na}_{2} \mathrm{HPO}_{4}$; Merck-USA) with initial conductivity of $3.56 \mathrm{mS} / \mathrm{cm}$ and $\mathrm{pH} 6.5-7.0$. In order to prepare three different $\mathrm{NaCl}$ concentration solutions in analytes, G. sulfurreducens medium was added with $\mathrm{NaCl}$ salt so that the final concentrations of $\mathrm{NaCl}$ in the medium are 2.0, 4.0, and $8.0 \mathrm{~g} / \mathrm{L}$ (initial conductivity of $13.61-18.70 \mathrm{mS} / \mathrm{cm}$ and $\mathrm{pH}$ 7.2-7.4).

\section{Operating condition of the MSC}

The inoculation of microorganism seed in the anode chamber was conducted initially. A $40.0 \mathrm{ml}$ of mixed seed microorganisms consisted of $140 \mathrm{ml}$ Geobacter medium, $10 \mathrm{ml}$ trace element, and $10 \mathrm{ml}$ vitamin were inoculated into the anode chamber. The Optical Density $\left(\mathrm{OD}_{600}\right)$ were measured on day 1 (24 h) and day 2 (48 h),. During the inoculation phase, the voltage was monitored. On day 4, $140 \mathrm{ml}$ anolyte was replaced with a medium with $2.0 \mathrm{~g} / \mathrm{L} \mathrm{NaCl}$ running for 4 days. Subsequently, anolyte was replaced with other $\mathrm{NaCl}$ concentrations $(4.0 \mathrm{~g} / \mathrm{L}$ and $8.0 \mathrm{~g} / \mathrm{L} \mathrm{NaCl}$, respectively for 5 days) and the same method was performed as before. During the running phase, current, voltage, $\mathrm{pH}$, conductivity and COD were measured. A capacitor with a capacity of $2.50 \mathrm{~V}$ of $820 \mu \mathrm{f}$ was installed in the system during the experiment.

\section{Analysis and calculation}

Current and voltage were observed as opencircuit voltage (OCV) using potentiostat (Model DY 2023, Digi-Ivy Inc, USA) recorded for every 100 seconds and voltmeter (365A PC USB Digital Data Logger, Hantek, China). The COD was measured according to standard methods, $\mathrm{pH}$ was measured using $\mathrm{pH}$ meter (model KW06-744, Krisbow, Indonesia), and conductivity was measured using conductivity meter (TES-1381K, TES Electrical Electronic Corp, Taiwan). The $\mathrm{OD}_{600}$ was measured using a UV-VIS spectrophotometer (UV VIS 1800, Shimadzu, Japan) at wavelength of $600 \mathrm{~nm}$. Coulombic Efficiency (\% CE) is the fraction of electrons transferred to the anode among the total electron, released by substrate oxidation, calculated according to Kim \& Logan (Kim and Logan, 2013). The performance of MSC was evaluated in terms of \% COD removal, power density, coulombic efficiency and the rise of conductivity (as it has a correlation with salinity).

\section{RESULTS AND DISCUSSION}

\section{Inoculation phase}

The inoculation experiment was aimed at growing the exoelectrogenic bacteria, specifically $G$. Sulfurreducens that can produce higher power density (Logan, 2009) which inoculated for 3 days. Voltage was observed for 3 days and the current was observed only for a day (Fig. 3).

On day $1, \mathrm{OD}_{600}$ was 0.52 and on day $2 \mathrm{OD}_{600}$ was 0.29 , then went constant on day 3 . As shown in Fig. 3, the voltage could reach as high as $1.20 \mathrm{~V}$ with a maximum current density achieved was $0.02 \mathrm{~A} / \mathrm{m}^{2}$. The current was considered to be still very low. The low current was subjected to the low concentration of substrate $(0.80 \mathrm{~g} / \mathrm{L}$ acetate) and wide distance between anode and cathode, as well as membrane resistivity, which could improve the ohmic loss in the systems (Verstraete and Rabaey, 2006). Moreover, the polarization was not performed during the experiment, so it also might affect the current and power production in the system (Logan, 2009).

\section{Running phase}

The running phase was started after the inoculation phase. In the running phase, anolyte with the addition of $2.0 \mathrm{~g} / \mathrm{L} \mathrm{NaCl}$ was run for 4 days, then continued with $\mathrm{NaCl} 4.0 \mathrm{~g} / \mathrm{L}$ running for 5 days, then $\mathrm{NaCl} 8.0 \mathrm{~g} / \mathrm{L}$ also running for 5 days. At the running phase, voltage and current were continuously observed, while $\mathrm{pH}$, conductivity, and COD were periodically measured.

Compared with the inoculation phase, as anolyte replaced with $2.0 \mathrm{~g} / \mathrm{L} \mathrm{NaCl}$ medium, the voltage dropped significantly at first then slightly increased from 0.29 to $0.52 \mathrm{~V}$. When anolyte was replaced with $4.0 \mathrm{~g} / \mathrm{L} \mathrm{NaCl}$ medium, the voltage was improved to a maximum of $0.8 \mathrm{~V}$. This result suggested that the anodophillic bacteria were affected by the increase of the salinity in the system. 


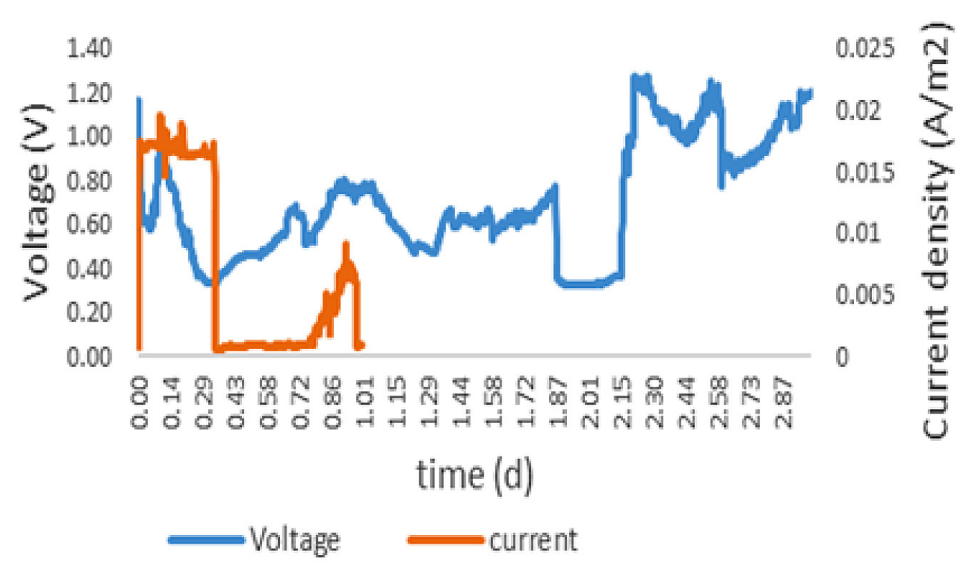

Figure 3. Voltage and current density of the MSC at inoculation phase

Since a mix culture was used, the anodophillic bacteria could easily be recovered and could regain their performance as conductivity increase at $4.0 \mathrm{~g} / \mathrm{L} \mathrm{NaCl}$ medium (Lefebvre et al., 2012). However, the voltage started to drop again when anolyte replaced with $8.0 \mathrm{~g} / \mathrm{L} \mathrm{NaCl}$ medium to a maximum of $0.33 \mathrm{~V}$. The gradual decrease of output voltage was occurred because of the increase of internal resistance, which also similar finding as reported by Tremoulli et al. (Tremouli et al., 2017) in the MFC system and Luo et al. (Luo et al., 2012) in the MDC system and also might have occurred due to the effect of oxygen diffusion as commonly occurred in a three chamber MFC model with aeration system (Wang et al., 2020).

Figure 4 (A) and Table 1 show that the highest performance (in terms of voltage, conductivity value, and power density) occurred when the $\mathrm{NaCl}$ concentration was $4.0 \mathrm{~g} / \mathrm{L}$. Higher voltage means higher energy generation and current production, while higher conductivity means a higher number of concentrated ions that go through the membranes. In the salinity chamber, at $\mathrm{NaCl}$ $2.0 \mathrm{~g} / \mathrm{L}$, conductivity increased from $50.54 \mu \mathrm{S} / \mathrm{cm}$ to $0.74 \mathrm{mS}$ and produced current density $0.03 \mathrm{~A} / \mathrm{m}^{2}$ and power density of $42.76 \mathrm{~mW} / \mathrm{m}^{2}$. At $4.0 \mathrm{~g} / \mathrm{L}$, conductivity in the salinity chamber raised from 80.8 to $2.74 \mathrm{mS} / \mathrm{cm}$, corresponding to the increase of current density to $0.05 \mathrm{~A} / \mathrm{m}^{2}$ and power density increase to $53.37 \mathrm{~mW} / \mathrm{m}^{2}$. At $8.0 \mathrm{~g} / \mathrm{L}$, conductivity in the salinity chamber increased from 10.01 to $1.65 \mathrm{mS} / \mathrm{cm}$, corresponding to current density upsurge to $0.02 \mathrm{~A} / \mathrm{m}^{2}$ and power density of $29.29 \mathrm{~mW} / \mathrm{m}^{2}$. This result was relatively lower than reported by Kim and Logan (Kim and Logan, 2013) using MFCs, as they used a voltage of $1.0 \mathrm{~V}$ to produce higher current and power, as well as the stimulation of higher ions transfer to the salinity chamber. In turn, in this experiment, the system only relied on the oxidation of the substrate (COD) derived from $0.8 \mathrm{~g} / \mathrm{L}$ Na-acetate. However, the results of this study were similar to the those by Monzon et al., 2015 (Monzon et al., 2015) and Grattieri and Minteer, 2018 (Grattieri and Minteer, 2018) who concluded that power density increased and reached at certain peak due to raise of conductivity/salinity but then hypersaline condition would hinder the performance of electroactive anodophillic microorganisms that made power density dropped. Figure 4 (B) shows that COD removal has a positive correlation with the increase of conductivity in the salinity chamber, while $\% \mathrm{CE}$ has a reverse correlation with both COD removal and conductivity rise in the saline chamber. It shows that the electrons generated from organic oxidation in anode were more likely to be predominantly used to drive salt ions to the salinity chamber rather than to produce electricity, which also happened in the MDC system (Zhang and He, 2012).

Table 1 also shows the $\mathrm{pH}$ value during the experiment. At the beginning, the anolyte $\mathrm{pH}$ was $7.3-7.4$, while the catholyte $\mathrm{pH}$ was $6.35-6.5$. At the end of each cycle, $\mathrm{pH}$ of both anolyte and catholyte were slightly dropped to 5.5-6.3. The $\mathrm{pH}$ in catholyte did not significantly drop due to the effect of recirculation, similar to $\mathrm{Qu}$ et al. 2012 (Qu et al., 2012) who stated that recirculation process creates a $\mathrm{pH}$ balance between anolyte and catholyte. However, low $\mathrm{pH}(\mathrm{pH} 5-6)$ in the system resulted in low electricity generation in the MFC system, as also reported by $\mathrm{He}$ et al., 2008 (He et al., 2008) and Ren et al., 2017 (Ren et al., 2007). Apparently, the same condition was also applied in MSC system. Therefore, low electricity generation due to the low $\mathrm{pH}$ occurred 

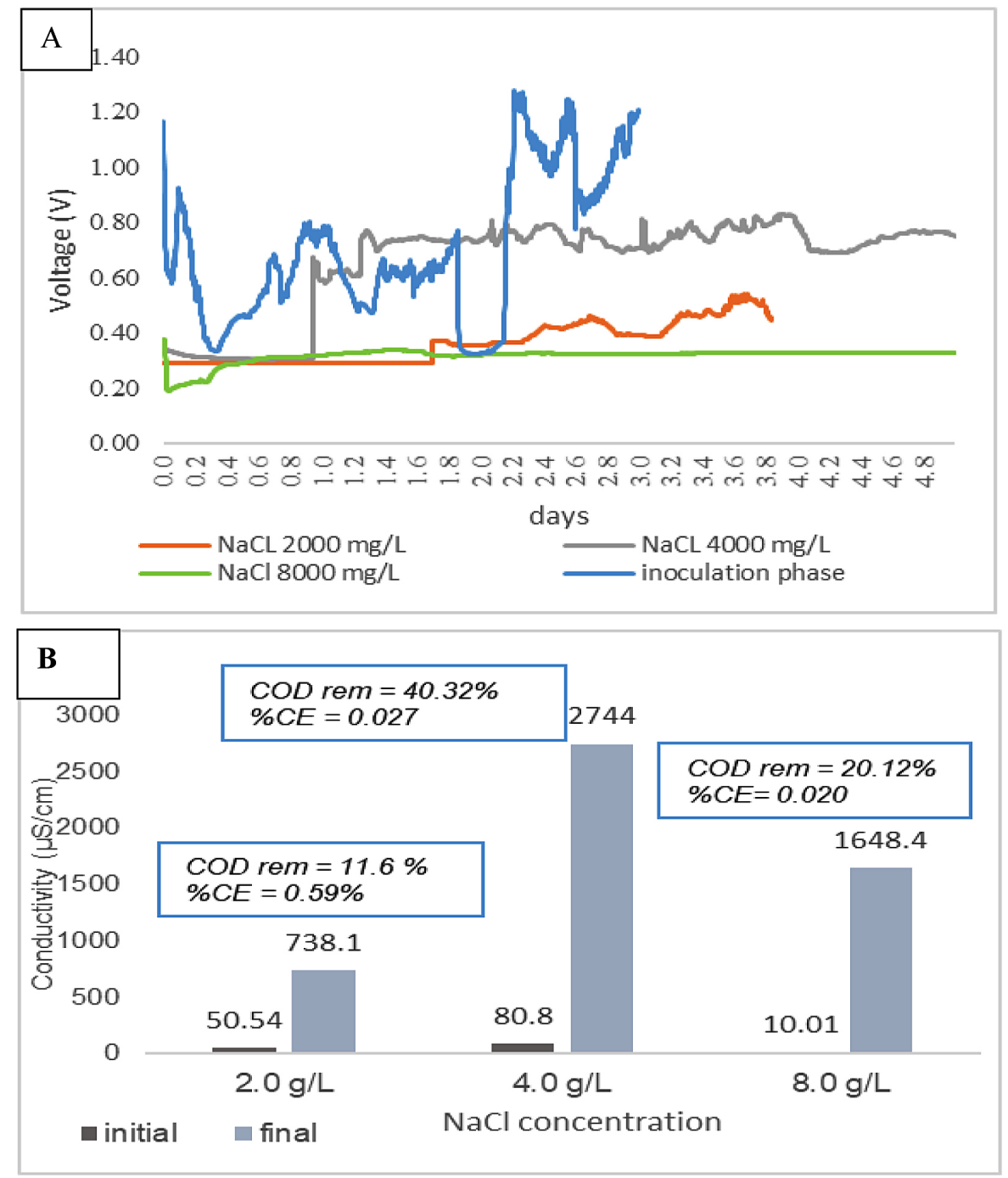

Figure 4. A) Voltage profile at different $\mathrm{NaCl}$ concentrations. B) Conductivity profile in the salinity chamber at the initial and the final of each cycle

and hence created low \% CE. A $2.0 \mathrm{~g} / \mathrm{L} \mathrm{NaCl}$ was found to be the highest value of coulombic efficiency $(0.59 \%)$, while $8.0 \mathrm{~g} / \mathrm{L} \mathrm{NaCl}$ is the lowest $\%$ CE $(0.02 \%)$. Low level of \%CE also might be due to the absence of external power to boost the current production and the reactor design (using triple chambers) that made the distance between electrodes too wide to be able to allow the electron flowing in the system (Mohan and Chandrasekhar, 2011).

\section{CONCLUSIONS}

Three chamber Microbial Salinity Cell (MSC) was successfully able to simultaneously generate electricity and remove salinity from highly saline organic wastewater. Installing a recirculation system in the MSC reactor proved to reduce the $\mathrm{pH}$ imbalance in the system. The performance of MSC is highly correlated with the initial $\mathrm{NaCl}$ concentration. An optimum $\mathrm{NaCl}$ concentration

Table 1. Summary performance of the MSC

\begin{tabular}{|c|c|c|c|c|c|c|c|c|}
\hline $\begin{array}{c}\mathrm{NaCl} \\
\text { concentration } \\
(\mathrm{g} / \mathrm{L})\end{array}$ & $\begin{array}{c}\text { COD } \\
\text { removal } \\
(\%)\end{array}$ & $\begin{array}{c}P \max \\
\left(\mathrm{mW} / \mathrm{m}^{2}\right)\end{array}$ & $\begin{array}{c}\operatorname{Imax}(A / \\
\left.m^{2}\right)\end{array}$ & CE (\%) & $\begin{array}{l}\text { pH initial } \\
\text { anolyte }\end{array}$ & $\begin{array}{l}\mathrm{pH} \text { final } \\
\text { anolyte }\end{array}$ & $\begin{array}{l}\mathrm{pH} \text { initial } \\
\text { catholyte }\end{array}$ & $\begin{array}{l}\mathrm{pH} \text { final } \\
\text { catholyte }\end{array}$ \\
\hline 2.0 & 11.68 & 42.76 & 0.03 & 0.59 & 7.41 & 6.00 & 6.50 & 6.00 \\
\hline 4.0 & 40.32 & 53.37 & 0.05 & 0.03 & 7.34 & 5.69 & 6.35 & 5.49 \\
\hline 8.0 & 20.12 & 29.29 & 0.03 & 0.02 & 7.20 & 6.30 & 6.35 & 5.50 \\
\hline
\end{tabular}


was found to be $4.0 \mathrm{~g} / \mathrm{L}$ which able to generate power up to $53.37 \mathrm{~mW} / \mathrm{m}^{2}$, resulting the highest conductivity of $2.74 \mathrm{mS} / \mathrm{cm}$. Comparing the coulombic efficiency, power, conductivity and $\%$ COD removal, the obtained results suggested that the electrons generated from organic oxidation in anode were predominantly used to drive salt from the anode to salinity chamber, rather than to produce electricity. Using the presented methodology, the MSC performance was still considerably low compared to the conventional MFC system. However, it will be interesting to foresee the industrial application of this technology by focusing on the improvement of power generation, salinity removal and the development of a robust bioanode in highly salinity wastewater.

\section{Acknowledgment}

This research was supported by KURITA-AIT Research Grant 2018 and Centre of Industrial Pollution Prevention Technology, Ministry of Industry of the Republic of Indonesia.

\section{REFERENCES}

1. Cao, X., Huang, X., Liang, P., Xiao, K., Zhou, Y., Zhang, X., Logan, B.E., 2009. A new method for water desalination using microbial desalination cells. Environ. Sci. Technol. 43, 7148-7152. https:// doi.org/10.1021/es901950j

2. Fornero, J.J., Rosenbaum, M., Cotta, M.A., Angenent, L.T., 2010. Carbon dioxide addition to microbial fuel cell cathodes maintains sustainable catholyte ph and improves anolyte ph, alkalinity, and conductivity. Environ. Sci. Technol. 44, 2728-2734. https://doi.org/10.1021/es9031985

3. Gebauer, R., 2004. Mesophilic anaerobic treatment of sludge from saline fish farm effluents with biogas production. Bioresour. Technol. 93, 155-167. https://doi.org/10.1016/j.biortech.2003.10.024

4. Geobacter Sulfurreducens Medium [WWW Document], 2016.

5. Grattieri, M., Minteer, S.D., 2018. Microbial fuel cells in saline and hypersaline environments: Advancements, challenges and future perspectives. Bioelectrochemistry 120, 127-137. https://doi. org/10.1016/j.bioelechem.2017.12.004

6. He, Z., Huang, Y., Manohar, A.K., Mansfeld, F., 2008. Effect of electrolyte $\mathrm{pH}$ on the rate of the anodic and cathodic reactions in an air-cathode microbial fuel cell. Bioelectrochemistry 74, 78-82. https://doi.org/10.1016/j.bioelechem.2008.07.007
7. Jannelli, N., Anna Nastro, R., Cigolotti, V., Minutillo, M., Falcucci, G., 2017. Low pH, high salinity: Too much for microbial fuel cells? Appl. Energy 192, 543-550. https://doi.org/10.1016/j. apenergy.2016.07.079

8. Kadir, A.A., Abdullah, S.R.S., Othman, B.A., Hasan, H.A., Othman, A.R., Imron, M.F., Ismail, N. 'Izzati, Kurniawan, S.B., 2020. Dual function of Lemna minor and Azolla pinnata as phytoremediator for Palm Oil Mill Effluent and as feedstock. Chemosphere 259. https://doi.org/10.1016/j. chemosphere.2020.127468

9. Kim, Y., Logan, B.E., 2013. Simultaneous removal of organic matter and salt ions from saline wastewater in bioelectrochemical systems. Desalination 308, 115-121. https://doi.org/10.1016/j. desal.2012.07.031

10. Lefebvre, O., Tan, Z., Kharkwal, S., Ng, H.Y., 2012. Effect of increasing anodic $\mathrm{NaCl}$ concentration on microbial fuel cell performance. Bioresour. Technol. 112, 336-340. https://doi.org/10.1016/j. biortech.2012.02.048

11. Liu, H., Cheng, S., Logan, B.E., 2005. Power generation in fed-batch microbial fuel cells as a function of ionic strength, temperature, and reactor configuration. Environ. Sci. Technol. 39, 5488-5493. https://doi.org/10.1021/es050316c

12. Logan, B.E., 2009. Exoelectrogenic bacteria that power microbial fuel cells. Nat. Rev. Microbiol. 7, 375-81. https://doi.org/10.1038/nrmicro2113

13. Luo, H., Xu, P., Roane, T.M., Jenkins, P.E., Ren, Z., 2012. Microbial desalination cells for improved performance in wastewater treatment, electricity production, and desalination. Bioresour. Technol. 105, 60-66. https://doi.org/10.1016/j. biortech.2011.11.098

14. Ma, C., Jin, R.C., Yang, G.F., Yu, J.J., Xing, B.S., Zhang, Q.Q., 2012. Impacts of transient salinity shock loads on Anammox process performance. Bioresour. Technol. 112, 124-130. https://doi. org/10.1016/j.biortech.2012.02.122

15. Mehanna, M., Saito, T., Yan, J., Hickner, M., Cao, X., Huang, X., Logan, B.E., 2010. Using microbial desalination cells to reduce water salinity prior to reverse osmosis. Energy Environ. Sci. 3, 1114-1120. https://doi.org/10.1039/c002307h

16. Mohan, S.V., Chandrasekhar, K., 2011. Solid phase microbial fuel cell (SMFC) for harnessing bioelectricity from composite food waste fermentation: Influence of electrode assembly and buffering capacity. Bioresour. Technol. 102, 7077-7085. https:// doi.org/10.1016/j.biortech.2011.04.039

17. Monzon, O., Yang, Y., Yu, C., Li, Q., Alvarez, P.J.J., 2015. Microbial fuel cells under extreme salinity: Performance and microbial analysis. Environ. Chem. 
12, 293-299. https://doi.org/10.1071/EN13243

18. Qu, Y., Feng, Y., Wang, X., Liu, J., Lv, J., He, W., Logan, B.E., 2012. Simultaneous water desalination and electricity generation in a microbial desalination cell with electrolyte recirculation for $\mathrm{pH}$ control. Bioresour. Technol. 106, 89-94. https://doi. org/10.1016/j.biortech.2011.11.045

19. Ren, Z., Ward, T.E., Regan, J.M., 2007. Electricity production from cellulose in a microbial fuel cell using a defined binary culture. Environ. Sci. Technol. 41, 4781-4786. https://doi.org/10.1021/es070577h

20. Rousseau, R., Santaella, C., Achouak, W., Godon, J.J., Bonnafous, A., Bergel, A., Délia, M.L., 2014. Correlation of the Electrochemical Kinetics of HighSalinity-Tolerant Bioanodes with the Structure and Microbial Composition of the Biofilm. ChemElectroChem 1, 1966-1975. https://doi.org/10.1002/ celc. 201402153

21. Sulfurovum lithotrophicum methanogenium medium (h 2 /co 2 ) DSMZ 141 [WWW Document], 2014.

22. Tangahu, B.V., Ningsih, D.A., Kurniawan, S.B., Imron, M.F., 2019. Study of BOD and COD Removal in Batik Wastewater using Scirpus grossus and Iris pseudacorus with Intermittent Exposure System. J. Ecol. Eng. 20, 130-134. https://doi. org/10.12911/22998993/105357

23. Tremouli, A., Martinos, M., Lyberatos, G., 2017. The Effects of Salinity, $\mathrm{pH}$ and Temperature on the Performance of a Microbial Fuel Cell. Waste and Biomass Valorization 8, 2037-2043. https://doi. org/10.1007/s12649-016-9712-0

24. Verstraete, W., Rabaey, K., 2006. Critical Review Microbial Fuel Cells : Methodology and Technology $†$ 40, 5181-5192.

25. Wang, C., Shen, J., Chen, Q., Ma, D., Zhang, G., Cui, C., Xin, Y., Zhao, Y., Hu, C., 2020. The inhibiting effect of oxygen diffusion on the electricity generation of three-chamber microbial fuel cells. J. Power Sources 453, 227889. https://doi. org/10.1016/j.jpowsour.2020.227889

26. Wang, H., Ren, Z.J., 2013. A comprehensive review of microbial electrochemical systems as a platform technology. Biotechnol. Adv. 31, 1796-807. https:// doi.org/10.1016/j.biotechadv.2013.10.001

27. Yuliasni, R., Setianingsih, N.I., Wicaksono, K.A., Harihastuti, N., 2018. Influence of Operational Condition on the Performance of Halotolerant Enriched - Activated Sludge System for Treating Medium Salinity Peanut Roasted Wastewater. J. Ris. Teknol. Pencegah. Pencemaran Ind. 9, 46. https:// doi.org/10.21771/jrtppi.2018.v9.no2.p46-54

28. Zhang, B., He, Z., 2012. Integrated salinity reduction and water recovery in an osmotic microbial desalination cell. RSC Adv. 2, 3265-3269. https:// doi.org/10.1039/c2ra20193c

29. Zhang, L., Fu, G., Zhang, Z., 2019. Electricity generation and microbial community in longrunning microbial fuel cell for high-salinity mustard tuber wastewater treatment. Bioelectrochemistry 126, 20-28. https://doi.org/10.1016/j. bioelechem.2018.11.002 